\title{
Family studies of congenital heart block associated with Ro antibody
}

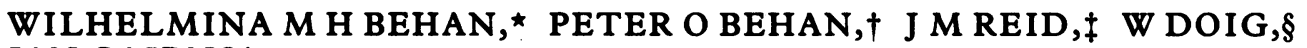 \\ JAN GAIRNS $\dagger$

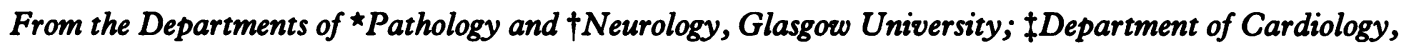 \\ Western Infirmary; §Department of Paediatric Cardiology, Royal Hospital for Sick Children, Glasgow
}

SUMMARY Complete congenital heart block is associated with the presence of maternal autoantibodies to small ribosomal nucleoproteins (such as anti-Ro) which cross the placenta and may be deposited at the site of cardiac damage. Ten such cases of congenital heart block, their mothers, and their siblings were studied. The seropositive mother of one case had a similar conduction defect (bifascicular block) to that in her affected child. None of the siblings examined had cardiac lesions. Six mothers had Ro or La antibody five to 17 years after the birth of the affected child. Four mothers examined 11-32 years after the birth of an affected child were seronegative. Three of these mothers had evidence of a connective tissue disorder. This evidence is consistent with a hypothesis that a maternal viral infection, associated with autoantibody production, leads to virus crossing the placenta, damaging the fetal heart, and eliciting local deposition of maternal antibody.

The development of complete congenital heart block is associated with the transplacental passage of maternal autoantibodies directed at small ribosomal nucleoproteins. ${ }^{1-3}$ Most mothers who give birth to an affected infant have anti-Ro or the related anti-La serum antibody, as do their infants up to three months after birth. ${ }^{134}$ Immunoglobulins thought to be of maternal origin were found at the site of cardiac damage in one baby who died three days after birth. ${ }^{2}$ A mother who gives birth to such an infant may or may not have a connective tissue disease at the time, but $30-60 \%$ of these women will develop such an illness subsequently. ${ }^{1-5}$ There are, however, several unanswered questions-for example, what is the risk of subsequent offspring being affected? Are the two sexes at equal risk (affected males tend to have complete congenital heart block only while affected females show other stigmata of the neonatal lupus syndrome ${ }^{3}$ ), and, because the antibody seems to produce such severe damage to fetal myocardium, what is its long term effect on adult heart tissue?

To try and answer these questions we investigated 10 individuals who had this isolated cardiac abnormality and their mothers.

Requests for reprints to Dr Wilhelmina M H Behan, Department of Pathology, Western Infirmary, Dumbarton Road, Glasgow G11 6NT.

Accepted for publication 9 May 1989

\section{Patients and methods}

CASES OF COMPLETE CONGENITAL HEART BLOCK Table 1 gives the clinical details of the 10 cases (five male and five female patients). Six of them had had permanent pacemakers inserted. One was diagnosed in utero, four were identified in the neonatal period, and the others at ages from 18 months to 20 years. They are currently 5-32 years old.

\section{DETECTION OF ANTIBODIES}

Serum samples were stored at $-70^{\circ} \mathrm{C}$ until use and then heat inactivated before testing. Antinuclear and anti-DNA antibodies were sought by standard indirect immunofluorescence techniques, with rat liver and Crithidia luciliae as the respective substrates. ${ }^{67}$ Rheumatoid factor was assayed by a $N$ commercial latex agglutination test (Rheumaton) $N$ followed with an enzyme linked immunoadsorbent $N$ assay of positive samples for IgM. Antibodies to $\sigma$ soluble cellular antigens were detected by means of saline extracts of human spleen (a potent source of Ro $\frac{D}{D}$ antigen and the other nucleoprotein complexes-Sm and nuclear ribosomal nucleoprotein (nRNP)) and 7 fresh calf thymus (for the detection of La (SS-B)), prepared as described. ${ }^{8}$ The serum was screened first $\vec{D}$ by double immunodiffusion and then by counterim- $\frac{\vec{D}}{\Phi}$ munoelectrophoresis. ${ }^{9}$ Known control antisera were $\frac{\varrho}{\sigma}$ incorporated; all positive results were confirmed by 
Table 1 Clinical data on 10 cases of complete congenital heart block

\begin{tabular}{|c|c|c|c|c|c|c|c|c|c|c|}
\hline \multirow[b]{2}{*}{ Data } & \multicolumn{10}{|l|}{ Patient } \\
\hline & 1 & 2 & 3 & 4 & 5 & 6 & 7 & 8 & 9 & 10 \\
\hline $\begin{array}{l}\text { Sex } \\
\text { Age at diagnosis } \\
\text { Pacemaker inserted } \\
\text { Present age (yr) }\end{array}$ & $\begin{array}{l}\text { M } \\
\text { Neonate } \\
\text { Yes } \\
5\end{array}$ & $\begin{array}{l}\text { F } \\
\text { Neonate } \\
\text { Yes } \\
7\end{array}$ & $\begin{array}{l}\text { M } \\
\text { Neonate } \\
\text { Yes } \\
10\end{array}$ & $\begin{array}{l}\text { M } \\
\text { In utero } \\
\text { No } \\
10\end{array}$ & $\begin{array}{l}\text { F } \\
18 \text { mnth } \\
\text { Yes } \\
17\end{array}$ & $\begin{array}{l}\text { F } \\
5 \text { yr } \\
\text { No } \\
12\end{array}$ & $\begin{array}{l}\text { M } \\
\text { Neonate } \\
\text { No } \\
16\end{array}$ & $\begin{array}{l}M \\
3 \mathrm{yr} \\
\text { No } \\
17\end{array}$ & $\begin{array}{l}\text { F } \\
20 \text { yr } \\
\text { Yes } \\
21\end{array}$ & $\begin{array}{l}\text { F } \\
17 \text { yr } \\
\text { Yes } \\
32\end{array}$ \\
\hline
\end{tabular}

the demonstration of a complete reaction of identity with one of the positive controls, obtained with the help of Dr P J Maddison, Dr G R V Hughes, and the Center for Disease Control, Atlanta; the center also supplied anti-La, anti-nRNP, and anti-Sm antisera (antisera to related nuclear antigens). Control sera were obtained from a group of $\mathbf{4 0}$ pregnant women, age-matched for the mothers tested.

The Ouchterlony plates were examined at 24, 48, 72 , and 96 hours. The counterimmunoelectrophoresis plates were left overnight at room temperature, then washed in $5 \%$ citrate for four hours, in saline for $\mathbf{4 8}$ hours, and stained with Coomassie blue.

\section{Results}

Table 2 shows the results of examining the mothers. Their ages at the time of birth of the affected child ranged from 22 years to 43 years. They are currently from five to 32 years older. Five have a connective tissue disease ( 1 dermatomyositis and 4 rheumatoid arthritis). The mothers of cases 1 and 5 developed severe dermatomyositis and rheumatoid arthritis respectively before any of their children were born. The other mothers (of cases 8,9 and 10) developed arthritis after the birth of the affected infant. The mother of case 7 had rheumatic fever aged 12 years and since then has taken prophylactic antibiotics before any dental procedure.

Only the mother of case 1 , who has been taking prednisolone $5 \mathrm{mg}$ per day for the past 12 years, complained of cardiac symptoms-she had exertional dyspnoea. Detailed questioning elicited no complaints from the other mothers. None was hypertensive. Eight underwent electrocardiography and echocardiography. The mother of case 8 was too anxious to attend for investigation while the mother (aged 71 years) of case 10 had fallen and was unable to attend the hospital.

Table 2 Data on the mothers of 10 cases of complete congenital heart block

\begin{tabular}{|c|c|c|c|c|c|c|c|c|c|c|}
\hline & \multicolumn{10}{|c|}{ Mother of case: } \\
\hline & 1 & 2 & 3 & 4 & 5 & 6 & 7 & 8 & 9 & 10 \\
\hline $\begin{array}{l}\text { Mother's age at } \\
\text { birth of affected } \\
\text { child }\end{array}$ & 27 & 29 & 25 & 31 & 22 & 25 & 39 & 43 & 25 & 39 \\
\hline $\begin{array}{l}\text { Mother's present } \\
\text { age with interval } \\
\text { since the birth in } \\
\text { brackets }\end{array}$ & $32(5)$ & $38(7)$ & $35(10)$ & $41(10)$ & $39(17)$ & $36(11)$ & $55(16)$ & $60(17)$ & $46(21)$ & $71(32)$ \\
\hline Maternal illnesses & $\begin{array}{l}\text { Dermato- } \\
\text { myositis } \\
\text { for } 15 \mathrm{yr}\end{array}$ & - & - & - & $\begin{array}{l}\text { Mild } \\
\text { rheumatoid } \\
\text { arthritis } \\
\text { for } 18 \text { yr }\end{array}$ & - & $\begin{array}{l}\text { Rheumatic } \\
\text { fever aged } \\
12 \text { yr. } \\
\text { Healthy } \\
\text { since then }\end{array}$ & $\begin{array}{l}\text { Moderately } \\
\text { severe } \\
\text { arthritis } \\
\text { for } 10 \mathrm{yr}\end{array}$ & $\begin{array}{l}\text { y Rheuma- } \\
\text { toid } \\
\text { arthritis } \\
\text { for a yr }\end{array}$ & $\begin{array}{l}\text { Rheuma- } \\
\text { toid } \\
\text { arthritis } \\
\text { for } 15 \mathrm{yr}\end{array}$ \\
\hline $\begin{array}{l}\text { Cardiac findings/ } \\
\text { symptoms }\end{array}$ & $\begin{array}{l}\text { Exertional } \\
\text { dyspnoea }\end{array}$ & - & - & - & 一 & - & - & - & - & 一 \\
\hline $\begin{array}{l}\text { Blood pressure } \\
\text { (mm Hg) }\end{array}$ & $130 / 80$ & $110 / 80$ & $130 / 80$ & $150 / 95$ & $120 / 70$ & $110 / 70$ & $145 / 90$ & Not done & $124 / 90$ & Not done \\
\hline $\begin{array}{l}\text { Electrocardiogram } \\
\text { and } \\
\text { echocardiogram }\end{array}$ & Normal & $\begin{array}{l}\text { Bifas- } \\
\text { cicular } \\
\text { branch } \\
\text { block }\end{array}$ & Normal & Normal & Normal & Normal & Normal & Not done & Normal & Not done \\
\hline $\begin{array}{l}\text { Antibodies present } \\
\text { to Ro, La, } \\
\text { antinuclear } \\
\text { (ANA), } \\
\text { rheumatoid } \\
\text { factor (RhF) }\end{array}$ & $\begin{array}{l}\text { Anti-Ro, } \\
\text { ANA } \\
\text { l/1000, } \\
\text { RhF + ve, } \\
\text { rheumatoid } \\
\text { IgM } 1500 \\
\text { units/ml }\end{array}$ & Anti-Ro & $\begin{array}{l}\text { Anti-Ro, } \\
\text { RhF + ve }\end{array}$ & $\begin{array}{l}\text { Anti-Ro, } \\
\text { ANA 1/64, } \\
\text { RhF + ve }\end{array}$ & Anti-Ro & None & $\begin{array}{l}\text { Anti-La, } \\
\text { ANA } \\
1 / 1000, \\
\text { anti-DNA } \\
+ \text { ve }\end{array}$ & $\begin{array}{l}\text { None, } \\
\text { RhF + ve }\end{array}$ & $\begin{array}{l}\text { None, } \\
\text { RhF + ve }\end{array}$ & None \\
\hline
\end{tabular}


Table 3 Family relationships in individuals with complete congenital heart block

\begin{tabular}{|c|c|c|c|c|c|c|c|c|c|c|}
\hline \multirow[b]{2}{*}{ Present age (yr) } & \multicolumn{10}{|l|}{ Case No } \\
\hline & $\begin{array}{l}1 \\
5\end{array}$ & $\begin{array}{l}2^{\star} \\
7\end{array}$ & $\begin{array}{l}3 \\
10\end{array}$ & $\begin{array}{l}4 \\
10\end{array}$ & $\begin{array}{l}5^{\star} \\
17\end{array}$ & $\begin{array}{l}6^{\star} \\
11\end{array}$ & $\begin{array}{l}7 \\
16\end{array}$ & $\begin{array}{l}8 \\
17\end{array}$ & $\begin{array}{l}9 \star \\
21\end{array}$ & $\begin{array}{l}10 \\
32\end{array}$ \\
\hline $\begin{array}{l}\text { Birth order } \\
\text { Siblings }\end{array}$ & $\begin{array}{l}\text { Youngest } \\
\text { of } 3 \\
\text { Sister } \\
\text { aged } 11 . \\
\text { Brother } \\
\text { aged } 10\end{array}$ & $\begin{array}{l}\text { Second } \\
\text { of } 3 \\
\text { Brother } \\
\text { aged } 10 . \\
\text { Brother } \\
\text { aged } 18 \\
\text { mnth }\end{array}$ & $\begin{array}{l}\text { Younger } \\
\text { of } 2 \\
\text { Sister } \\
\text { aged } 13\end{array}$ & $\begin{array}{l}\text { Younger } \\
\text { of } 2 \\
\text { Brother } \\
\text { aged } 13\end{array}$ & $\begin{array}{l}\text { Elder } \\
\text { of } 2 \\
\text { Brother } \\
\text { aged } 16 .\end{array}$ & $\begin{array}{l}\text { Elder } \\
\text { of } 2 \\
\text { Sister } \\
\text { aged } 8\end{array}$ & $\begin{array}{l}\text { Youngest } \\
\text { of } 3 \\
\text { Brother } \\
\text { aged } 28 . \\
\text { Brother } \\
\text { aged } 25\end{array}$ & $\begin{array}{l}\text { Youngest } \\
\text { of } 6 \\
\text { Sisters } \\
\text { aged } 33 \text {, } \\
31 \text {, and } 27 \\
\text { yr, then } \\
\text { miscarriage. } \\
\text { Brother } \\
\text { aged } 23\end{array}$ & $\begin{array}{l}\text { Third } \\
\text { of } 4 \\
\text { Sister } \\
\text { aged } 26 \text {, } \\
\text { then still- } \\
\text { born } \\
\text { anence- } \\
\text { phalic. } \\
\text { Sister } \\
\text { aged } 20\end{array}$ & $\begin{array}{l}\text { Youngest } \\
\text { of } 3 \\
\text { Brother } \\
\text { aged } 43 \text {, } \\
\text { then } \\
\text { miscarriage }\end{array}$ \\
\hline
\end{tabular}

^Subsequent normal delivery.

The only abnormality detected was in the mother (aged 38) of case 2, who was a non-smoker and who had partial right bundle branch block with left axis deviation. She had no evidence of ischaemic heart disease. Five mothers had Ro antibody, when tested five to 17 years after delivery and one had La antibody, at 16 years after delivery. Four mothers, examined at 11 to 32 years later, were seronegative. Two years previously the same results had been found. Six mothers had a connective tissue disease with positive serology. The mothers of cases 1 and 7 had high titres (1/1000) of antinuclear antibodies, and the mother of case 7 also had DNA antibodies, indicative of systemic lupus erythematosus. Five mothers (of cases $1,3,4,8$, and 9) had sera positive for rheumatoid factor. None had antibodies to the related extractable nuclear antigens, Sm or nRNP.

The affected individuals (cases 5 to 10 ) were themselves tested for the same panel of antibodies and were, as expected, all negative.

Table 3 shows the family relationships. Each case of congenital heart block had one or more siblings. The older ones had been examined by a cardiologist at the time the index case was diagnosed and none was found to have any evidence of cardiac disease. Four families had children born after the affected child, from one to eight years later, and all of these had undergone cardiac evaluation with electrocardiograms and had been found to be normal. The other six patients were the youngest in their families; the births of three of them were preceded by miscarriages.

We looked at three generations in the family of one patient (case 9) who was herself seronegative as expected. She recently gave birth to a healthy son.

\section{Discussion}

Complete congenital heart block is a rare cardiac lesion, occurring as an isolated finding in approxi- mately 15 of 20000 live births, ${ }^{10}$ but it accounts for one in 200 referrals to specialised cardiac centres and is of considerable importance since those affected require lifelong cardiac supervision, usually with the insertion of a series of pacemakers. ${ }^{10}$ Although the condition was originally described in $1901^{11}$ and the first case of an affected infant with a mother who had systemic lupus erythematosus was reported in $1945,{ }^{12}$ it was not until 1977 that the consistent relation of this heart lesion to maternal connective tissue disease was established. ${ }^{13}$ Weston et al then suggested that the SS-A (Ro) antibody might be a serological marker for the neonatal lupus syndrome, including congenital heart block. ${ }^{14}$ The suggestion was quickly confirmed by work showing that 34 of 41 mothers who had an affected infant had anti-Ro serum autoantibody, as did seven of eight of their infants. ${ }^{1}$ Half of the mothers also had the related La antibody, which may be exclusively associated with Ro but no other autoantibodies. ${ }^{3}$ Since then, it has been postulated that the maternal autoantibody actually causes the cardiac damage, because maternal immunoglobulin, with or without complement, was found in the hearts of affected infants. ${ }^{215}$

Two questions immediately arise. What is the risk to the child of a mother who is seropositive for antiRo and what may be the long term effect of the antibody on the mother herself? In attempting to answer them, we concluded that the antibody itself cannot be the damaging agent although it may provide a clue to the pathogenesis.

Our group of mothers was typical of those previously described, with specific antibodies in six mothers and three of the four seronegative women having developed a connective tissue disease. They were tested 11-32 years after the birth of an affected child, which may explain their seronegativity. One mother did not have any positive immunological results but she is only 36 years old.

An unexpected finding, not previously recorded in any such mothers, was that of partial right bundle 
branch block with left axis deviation, indicating bifascicular conduction damage, in the mother of case 2. She was an energetic, normotensive woman of 38, a non-smoker, with no evidence of ischaemic heart disease but this result showed that she had evidence of conduction damage similar to that of her middle son. None of the other seven women had any abnormality, although the connective tissue disorders, which four of them had, are known to be associated with such cardiac lesions. These were dermatomyositis, ${ }^{16}{ }^{17}$ rheumatoid arthritis, ${ }^{18}$ and systemic lupus erythematosus. ${ }^{19}$ It is plain, therefore, that even in predisposed mothers, the Ro antibody may be present for up to 17 years without causing any injury to the maternal conduction system.

As for the risk to the child of a seropositive mother, all our cases had unaffected siblings-older, younger, or both. Four children, the younger siblings of cases $2,5,6$, and 9 were undoubtedly exposed to maternal Ro antibody, while others (of cases 1,8,9, and 10) are likely to have been at risk. The mother of case 1 had had severe dermatomyositis (a disorder in which Ro antibodies may appear ${ }^{17}$ ) since before the birth of any of her three children, while the other mothers were each delivered of a stillbirth immediately before the birth of their affected infant. Ro antibody is undoubtedly associated with fetal loss. ${ }^{120}$ In summary, the ten mothers had a total of 30 pregnancies with at least 18 fetuses exposed to Ro antibody: 10 developed heart block, three died, and five were unaffected healthy infants.

Similar anomalous findings have been reported before. They include the birth of dizygous twins, one affected and one not, and three healthy mother and infant anti-Ro seropositive pairs among 300 randomly selected pregnancies. ${ }^{1321}$ The explanations advanced previously have included possible fluctuations in antibody titre, differing maternal-fetal histocompatibility antigen $\mathrm{s}^{322}$ and a hormonal effect, because female infants are more commonly affected, ${ }^{34}$ but none of these has been substantiated.

The most telling facts against Ro antibody being the cause of the damage, however, are that first, the antigen against which it is directed is present not only in cardiac conduction tissue but in virtually every mammalian cell, ${ }^{23}$ including fetal tissue at 16-18 weeks' gestation ${ }^{24}$ (the earliest stage at which heart block has been detected). Secondly, since Ro is intracellular it should not elicit an immunemediated attack-although there is a possibility that it could appear on Purkinje cell membranes at a critical developmental stage. ${ }^{24}$

We would like to suggest a simple explanation for the anomalies in our study and those of others, namely that, before or during the early stage of pregnancy, the mother sustains a mild, perhaps unrecognised viral infection, to which she produces Ro or La antibodies. The virus crosses the placenta and damages the infant myocardium while specific maternal antibody, also crossing the placenta, localises in the same area. The infection in the child is selflimiting but it may persist in the mother so that a series of infants are affected. The mother's own heart may also be damaged (see case 2 ). An obvious viral candidate is a Coxsackie virus, since these viruses are common causes of myocarditis, ${ }^{25}$ show considerable sequence homology with certain intracellular proteins, ${ }^{26}$ and may persist in connective tissue diseases-for example dermatomyositis ${ }^{27}$ (see case 1).

\section{References}

1 Scott JS, Maddison PJ, Taylor PV, et al. Connective tissue disease, antibodies to ribonucleoproteins, and congenital heart block. N Engl J Med 1983;309: 209-12.

2 Litsey SE, Noonan JA, O'Connor WM, et al. Maternal connective tissue disease and congenital heart block. N Engl J Med 1985;312:98-100.

3 Lee LA, Weston WL. New findings in neonatal lupus syndrome. Am J Dis Child 1984;138:233-6.

4 Watson RM, Lane AT, Barnett NK, et al. Neonatal lupus erythematosus: a clinical, serological and immunogenetic study with review of the literature. Medicine (Baltimore) 1984;63:362-78.

5 Vetter VL, Rashkind WJ. Congenital complete heart block and connective-tissue disease. $N$ Engl J Med 1983;309:236-7.

6 Holborrow EJ, Weir DM, Johnson GD. A serum factor in lupus erythematosus with affinity for tissue nuclei. Br Med J 1957;ii:732-4.

7 Aarden LA, de Grott ER, Feltkamp TEW. Immunology of DNA. III. Crithidia luciliae: a simple substrate for the determination of anti-dsDNA with the immunofluorescence technique. Ann NY Acad Sci 1975;254:505-14.

8 Venables PJW, Smith PR, Maini RN. Purification and characterization of the Sjögren's syndrome A and B antigens. Clin Exp Immunol 1983;54:731-8.

9 Bunn CC, Gharavi AE, Hughes GRV. Antibodies to extractable nuclear antigens in 173 patients with DNA-binding positive SLE: an association between antibodies to ribonucleoproteins and $\mathrm{Sm}$ antigens observed by counterimmunoelectrophoresis. J Clin Lab Immunol 1982;8:13-7.

10 Cobbe SM. Congenital complete heart block. Br Med J 1983;286:1769-70.

11 Morquio L. Sur une maladie infantile et familiale caractérisée par des modifications permamentes du pouls, des attaques syncopales et epileptiformes et la mort subite. Archives de Medicine des Enfants 1901; 4:467-75.

12 Plant RK, Steven RA. Complete A-V block in a fetus: case report. Am Heart J 1945;30:615-8.

13 Chameides L, Truex RC, Vetter V, et al. Association of maternal systemic lupus erythematosus and congenital complete heart block. $N$ Engl J Med 
1977;297:1204-7.

14 Weston WL, Harmon C, Peebles C, et al. A serological marker for neonatal lupus erythematosus. $\mathrm{Br} J$ Dermatol 1982;107:377-82.

15 Taylor PV, Scott JS, Gerlis LM, et al. Maternal antibodies against fetal cardiac antigens in congenital complete heart block. $N$ Engl J Med 1986;315:667-72.

16 Askari AD, Huettner TL. Cardiac abnormalities in polymyositis/dermatomyositis. Semin Arthritis Rheum 1982;12:208-19.

17 Behan WMH, Behan PO, Gairns J. Cardiac damage in polymyositis associated with antibodies to tissue ribonucleoproteins. $\mathrm{Br}$ Heart $J$ 1987;57:176-80.

18 Villeco AS, de Liberali E, Branchi B, et al. Antibodies to cardiac conducting tissue and abnormalities of cardiac conduction in rheumatoid arthritis. Clin Exp Immunol 1983;53:536-40.

19 James TN, Rupe CE, Monto RW. Pathology of the cardiac conduction system in systemic lupus erythematosus. Ann Intern Med 1965;63:402-10.

20 Hull RG, Harris EN, Morgan SH, Hughes GRV. AntiRo antibodies and abortions in women with SLE. Lancet 1983;ii: 1138.

21 Calmes M, Bartholomew BA. SS-A (Ro) antibody in random mother-infant pairs. J Clin Pathol $\subseteq$ 1985;38:73-5.

22 Lockshin MD, Gibofsky A, Peebles CL, et al. Neonatal lupus erythematosus with heart block: family study of a patient with anti-SS-A and SS-B antibodies. Arthritis Rheum 1983;26:210-3.

23 Wolin SL, Steitz JA. The Ro small cytoplasmic ribonucleoproteins: identification of the antigenic protein and its binding site on the Ro RNAs. Proc Natl Acad Sci USA 1984;81:1996-2000.

24 Lee LA, Harmon CE, Huff JC, et al. The demonstration of SS-A/Ro antigen in human fetal tissues and in $\vec{\omega}$ neonatal and adult skin. J Invest Dermatol 1985; 85:143-6.

25 Woodruff JF. Viral myocarditis. A review. Am J Pathol 1980;101:427-529.

26 Walker EJ, Jeffrey PD. Sequence homology between $c$ encephalomyocarditis virus protein VPI and histidyl- $O$ tRNA synthetase supports a hypothesis of molecular $\frac{\text { ? }}{5}$ mimicry in polymyositis. Med Hypotheses 1988; 25:21-5.

27 Bowles NE, Sewry CA, Dubowitz V, et al. Dermatomyositis, polymyositis and Coxsackie-B-virus infection. Lancet 1987;i:1004-7. 